\title{
Xylitol production from lignocellulosic whole slurry corn cob by engineered industrial Saccharomyces cerevisiae PE-2
}

\author{
Sara L. Baptista, Joana T. Cunha, Aloia Romaní, Lucília Domingues* \\ CEB - Centre of Biological Engineering, University of Minho, 4710-057 Braga, Portugal
}

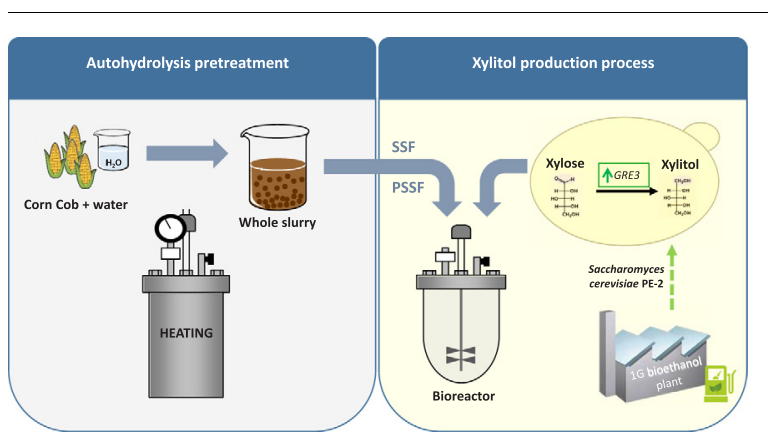

\section{A R T I C L E I N F O}

\section{Keywords:}

Xylitol production

Industrial Saccharomyces cerevisiae PE-2

GRE3 aldose reductase

Corn cob hemicellulosic hydrolysate

Presaccharification and simultaneous

saccharification and fermentation (PSSF)

\begin{abstract}
A B S T R A C T
In this work, the industrial Saccharomyces cerevisiae PE-2 strain, presenting innate capacity for xylitol accumulation, was engineered for xylitol production by overexpression of the endogenous GRE3 gene and expression of different xylose reductases from Pichia stipitis. The best-performing GRE3-overexpressing strain was capable to produce $148.5 \mathrm{~g} / \mathrm{L}$ of xylitol from high xylose-containing media, with a $0.95 \mathrm{~g} / \mathrm{g}$ yield, and maintained close to maximum theoretical yields $(0.89 \mathrm{~g} / \mathrm{g})$ when tested in non-detoxified corn cob hydrolysates. Furthermore, a successful integrated strategy was developed for the production of xylitol from whole slurry corn cob in a presaccharification and simultaneous saccharification and fermentation process (15\% solid loading and 36 FPU) reaching xylitol yield of $0.93 \mathrm{~g} / \mathrm{g}$ and a productivity of $0.54 \mathrm{~g} / \mathrm{L} \cdot \mathrm{h}$. This novel approach results in an intensified valorization of lignocellulosic biomass for xylitol production in a fully integrated process and represents an advance towards a circular economy.
\end{abstract}

\section{Introduction}

Concerns regarding the progressive exhaustion of the fossil resources, and the resultant environmental and economic problems, have created the necessity to replace the current petroleum-based economy. Lignocellulosic biomass, being the most abundant and renewable biomass available on earth, has been receiving growing attention as a substitute for the fossil fuels (Budzianowski, 2017). Lignocellulose presents a recalcitrant structure, mainly composed of cellulose (glucose monomers), hemicellulose (hexose and pentose sugars) and lignin; and the attainment of fermentable sugars from these biomasses requires pretreatment and hydrolysis steps that also result in the release of microbial inhibitory compounds (Zabed et al., 2016). In order to efficiently replace the petroleum based industry, the lignocellulose potential as a substrate for biofuels and value added chemicals must be fully exploited. In fact, the cellulosic fraction has already been extensively

\footnotetext{
* Corresponding author.

E-mail address: luciliad@deb.uminho.pt (L. Domingues).
} 
studied for the production of biofuels, nevertheless the attainment of a sustainable lignocellulose-based bioeconomy should include the valorization of the hemicellulose fraction for the production of value added products (Budzianowski, 2017).

Xylitol, a sugar alcohol, has been identified as one of the 12-top value added compounds to be attained from biomass (Petersen and Werpy, 2004). It is a natural sweetener used as a sugar substitute in food and pharmaceutical industries, as it presents advantageous properties, such as, low energy content, insulin-independent metabolism, anticariogenecity, among other pharmacological properties (de Albuquerque et al., 2014). Furthermore, xylitol can also be used in the chemical industry as an intermediate for the synthesis of polymers (Isikgor and Becer, 2015). Currently, xylitol is industrially produced through chemical hydrolysis and hydrogenation of xylan, an expensive and laborious process. Furthermore, even using lignocellulose as a raw material, it is not an environmental-friendly process, resulting in a growing interest in the microbiological production of xylitol (Mohamad et al., 2015).

Several yeast, such as $P$. stipitis (Scheffersomyces stipitis), Debaryomyces hansenii, Kluyveromyces marxianus and Candida spp, are naturally capable of consuming xylose through a xylose reductase/xylitol dehydrogenase (XR/XDH) pathway, which converts xylose into xylitol, and subsequently to xylulose. Xylitol is a common by-product of this pathway, mainly resultant of the co-factor imbalance between the reaction catalyzed by the $\mathrm{NAD}(\mathrm{P}) \mathrm{H}$-dependent xylose reductase (normally with preference for NADPH) and the NAD+-dependent xylitol dehydrogenase (de Albuquerque et al., 2014). Considering these, yeast that are naturally capable of xylose consumption have been extensively studied for xylitol production (Dasgupta et al., 2017; Kumar et al., 2018; López-Linares et al., 2018), nevertheless the yields of xylitol from xylose are limited by the use of xylose for yeast growth and maintenance energy. In this sense, the use of $S$. cerevisiae, (a GRAS microorganism naturally incapable of xylose metabolism) with increased expression of enzymes with xylose reductase activity has emerged as a solution to increase xylitol yields from xylose (Chung et al., 2002; Govinden et al., 2001; Hallborn et al., 1991; Kim et al., 2017; Kogje and Ghosalkar, 2016; Lee et al., 2000; Meinander and Hahn-Hägerdal, 1997), since it allows an easier control of the sugars directed for yeast metabolism. Furthermore, the use of $S$. cerevisiae strains isolated from industrial harsh conditions presents another advantage in terms of increased tolerance towards the presence of lignocellulosic-derived inhibitors, in comparison to laboratorial strains and non-Saccharomyces yeast (Pereira et al., 2014). In recent studies, the industrial S. cerevisiae PE-2, isolated from a first generation bioethanol plant, was found to be naturally prone to xylitol accumulation when expressing the XR/XDH pathway from $S$. stipitis (even using a NADH-preferable XR mutant). This accumulation was partially reverted by the deletion of GRE3 (Costa et al., 2017; Romani et al., 2015), a gene that codifies an unspecific aldose reductase (using NADPH as co-factor), previously reported to be responsible for xylitol accumulation in S. cerevisiae (Traff et al., 2001).

Despite the promising results already obtained with recombinant $S$. cerevisiae for xylitol production (Kim et al., 2017; Lee et al., 2000; Oh et al., 2013), only few work focus on lignocellulosic hydrolysates (Kogje and Ghosalkar, 2016, 2017) and there are no studies focusing on the valorization of both cellulosic and hemicellulosic fractions of the lignocellulosic biomass. Considering this, and the $S$. cerevisiae PE-2 potential for xylitol accumulation, this strain was used as chassis in this study to express the xylose reductase from $P$. stipitis, both the wild type and a mutant with preference for NADH, and to overexpress the endogenous GRE3 gene, to: (1) evaluate xylitol production in terms of enzyme and co-factor preference, (2) develop an efficient strategy for xylitol production through the valorization of corn cob whole slurry.
Table 1

Yeast strains, plasmids and primers used in this work. Upper case sequences correspond to sequences complementary to the template, and lower case sequences correspond to homologous recombination sites with the desired digested vectors.

\begin{tabular}{|c|c|c|}
\hline S. cerevisiae strains & Relevant Genotype & Reference \\
\hline CEN.PK 113-5D & MATa; ura3-52 & $\begin{array}{l}\text { Van Dijken } \\
\text { et al. (2000) }\end{array}$ \\
\hline PE-2 & $\begin{array}{l}\text { Diploid; Isolated from bio-ethanol plants } \\
\text { in } 1994\end{array}$ & $\begin{array}{l}\text { Basso et al. } \\
(2008)\end{array}$ \\
\hline $\mathrm{PE}-2-\mathrm{XR}_{\mathrm{wt}}$ & PE-2, p417-kan & This work \\
\hline $\mathrm{PE}-2-\mathrm{XR}_{\mathrm{mut}}$ & PE-2, p418-kan & This work \\
\hline PE-2-GRE3 & PE-2, p417-kan-GRE3 & This work \\
\hline CEN.PK 113-5D & CEN.PK 113-5D, p417-kan-GRE3 & This work \\
\hline Plasmids & Relevant Features & \\
\hline p417 & pYPK0_TEF1p_PsXYL1_TDH3t, URA3 & $\begin{array}{l}\text { Pereira et al. } \\
(2016)\end{array}$ \\
\hline p418 & $\begin{array}{l}\text { pYPK0_TEF1P_PsXYL1(N272D)_TDH3t, } \\
\text { URA3 }\end{array}$ & $\begin{array}{l}\text { Pereira et al. } \\
\text { (2016) }\end{array}$ \\
\hline p417-kan & pYPK0_TEF1p_PsXYL1_TDH3t, KanMX4 & This work \\
\hline p418-kan & $\begin{array}{l}\text { pYPK0_TEF1p_PsXYL1(N272D)_TDH3t, } \\
\text { KanMX4 }\end{array}$ & This work \\
\hline p417-kan-GRE3 & pYPK0_TEF1p_ScGRE3_TDH3t, KanMX4 & This work \\
\hline Primers & Sequence & \\
\hline KanMX4_FW & \multirow{5}{*}{\multicolumn{2}{|c|}{$\begin{array}{l}\text { ctcacgttaagggattttggtcatgag } \\
\text { CACATACGATTTAGGTGACACTATAGAAC } \\
\text { catctttgacagcttatcatcgataagctCGACTCACTATAGGGAGACC } \\
\text { ggaacgccaggttgcccactttctcactagtgaaaATGTCTTCACTGGTTAC } \\
\text { taaatcctgatgcgtttgtctgcacagatggcgcgTCAGGCAAAAGTGGGG }\end{array}$}} \\
\hline & & \\
\hline KanMX4_RV & & \\
\hline GRE3_TEF1_FW & & \\
\hline GRE3_TDH3_RV & & \\
\hline
\end{tabular}

\section{Materials and methods}

\subsection{Strains and plasmid construction}

The yeast strains used in this study are listed in Table 1. Escherichia coli NZy5 $\alpha$ (NZYTech) was used for plasmid propagation and maintenance. Yeast DNA transformation was carried out using the LiAC/SS carrier DNA/PEG method (Gietz and Schiestl, 2007). Yeast strains were maintained at $4{ }^{\circ} \mathrm{C}$ on YPD plates $(10 \mathrm{~g} / \mathrm{L}$ yeast extract, $20 \mathrm{~g} / \mathrm{L}$ peptone, $20 \mathrm{~g} / \mathrm{L}$ glucose and $20 \mathrm{~g} / \mathrm{L}$ agar). For recombinant yeast strains, liquid and solid YPD media were supplemented with $150 \mathrm{mg} / \mathrm{L}$ and $200 \mathrm{mg} / \mathrm{L}$ of geneticin (G418), respectively.

For the construction of $S$. cerevisiae PE-2 strains expressing a native $P$. spititis xylose reductase (XR) and a NADH-preferable xylose reductase mutant (XR-N272D) from $P$. spititis, the URA3 marker of the p417 and p418 vectors (Table 1) was replaced by the kanMX marker by in vivo homologous recombination: the kanMX geneticin resistance cassette was amplified from plasmid pUG6 (Guldener et al., 1996) with the primers KanMX4_FW and KanMX4_RV and co-transformed with the p417 and p418 vectors digested in the NheI restriction site (Fig. 1). Transformants were selected on YPD plates containing $200 \mu \mathrm{g} / \mathrm{mL}$ of G418. The resulting vectors were named p417-kan and p418-kan and the $S$. cerevisiae PE-2 strains carrying them were given the name PE-2$\mathrm{XR}_{\mathrm{wt}}$ and $\mathrm{PE}-2-\mathrm{XR}_{\text {mut }}$, respectively (Table 1 ). Additionally, to overexpress the GRE3 gene, a plasmid containing this gene was constructed by homologous recombination from the described above p417-kan. Briefly, the p417-kan plasmid was digested with AatII, to remove most of the XR_wt gene sequence, and co-transformed with the GRE3 gene, amplified with primers GRE3-TEF1-FW and GRE3-TDH3-RV from chromosomal DNA of PE-2 strain, originating the plasmid p417-kanGRE3 (Fig. 1). S. cerevisiae PE-2 and CENPK.113-5D transformants containing this plasmid were selected in YPD plates containing $200 \mu \mathrm{g} /$ $\mathrm{mL}$ of G418, and were named PE-2-GRE3 and CENPK.113-5D-GRE3, respectively. The correct recombination between the DNA molecules was confirmed by colony PCR. 

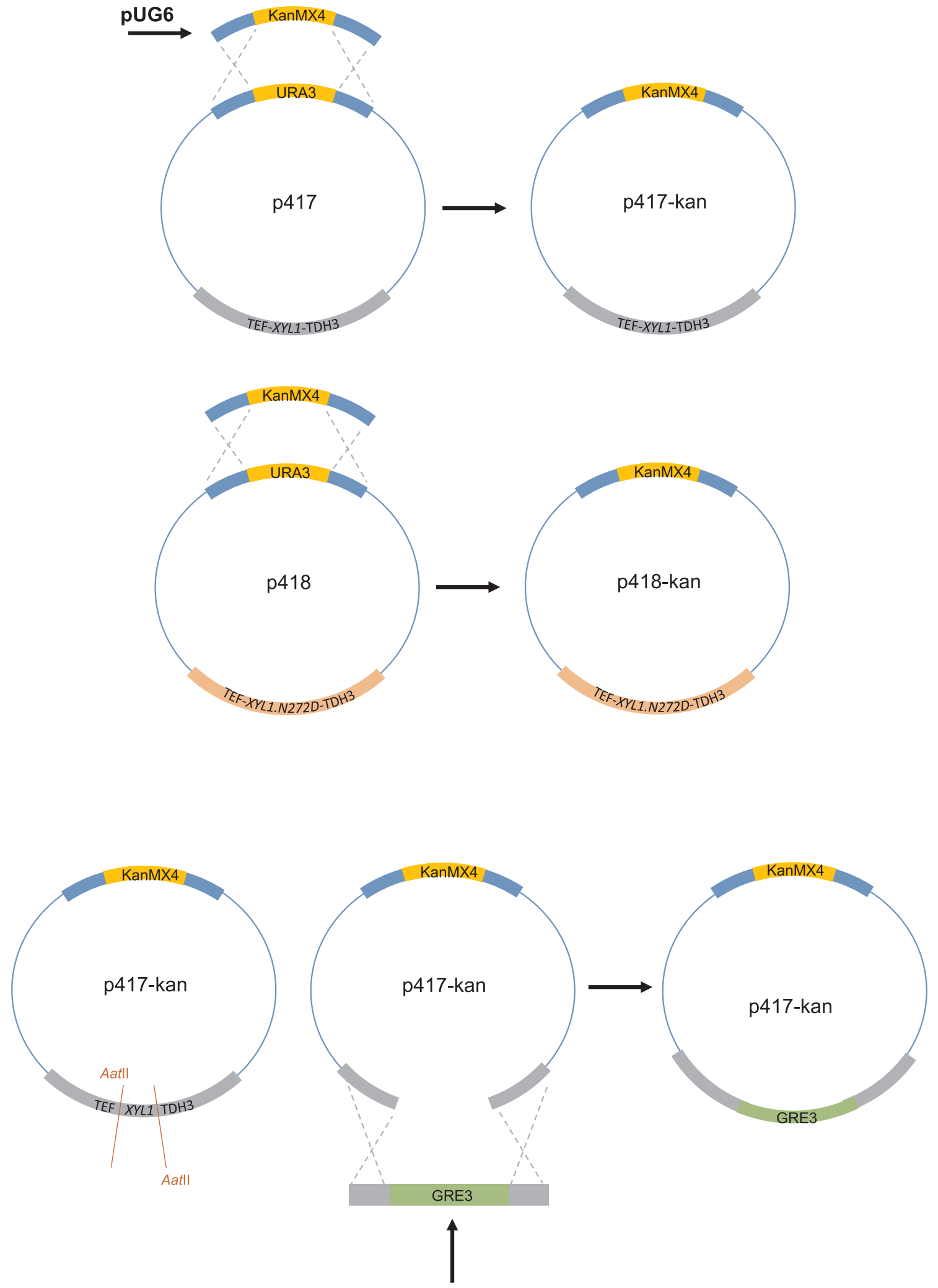

Saccharomyces cerevisiae PE-2

Genomic DNA

Fig. 1. Schematic representation of plasmids construction. 


\subsection{Inoculum}

Yeast cells for inoculation were grown overnight at $30{ }^{\circ} \mathrm{C}$ and $200 \mathrm{rpm}$ in Erlenmeyer flasks filled with YPD medium to $40 \%$ of their total volume. The cell suspension was collected by centrifugation for $5 \mathrm{~min}$ at $3000 \mathrm{rpm}, 4^{\circ} \mathrm{C}$ and suspended in $0.9 \%(\mathrm{w} / \mathrm{v})$ sodium chloride solution, in order to achieve a final concentration of $400 \mathrm{~g}$ fresh yeast/ L. The fermentation experiments were conducted with the concentrated cell suspension, with a cellular concentration from 9 to $11 \mathrm{~g}$ fresh yeast/ $\mathrm{L}$ (corresponding to $3-5 \mathrm{~g}$ of dry yeast/L).

\subsection{Fermentation experiments}

Batch experiments were carried out in complete YP medium $(20 \mathrm{~g} / \mathrm{L}$ peptone and $10 \mathrm{~g} / \mathrm{L}$ yeast extract) with $30 \mathrm{~g} / \mathrm{L}$ of xylose and $20 \mathrm{~g} / \mathrm{L}$ of glucose as carbon source, in $250 \mathrm{~mL}$ Erlenmeyer flasks (working volume $40 \mathrm{~mL}$ ) at $30^{\circ} \mathrm{C}$ and $200 \mathrm{rpm}$.

Fed-batch fermentations were performed in complete YP medium with $30 \mathrm{~g} / \mathrm{L}$ of glucose and different concentrations of xylose: $64.6 \mathrm{~g} / \mathrm{L}$, $126 \mathrm{~g} / \mathrm{L}$ and $159 \mathrm{~g} / \mathrm{L}$ and in corn cob hydrolysate medium (supplemented with $20 \mathrm{~g} / \mathrm{L}$ of peptone and $10 \mathrm{~g} / \mathrm{L}$ of yeast extract). These experiments were conducted in a 3.7 L Bioengineering's RALF bioreactor (working volume $2 \mathrm{~L}$ for synthetic media and $1.5 \mathrm{~L}$ for corn cob hydrolysate) at $30^{\circ} \mathrm{C}, 400 \mathrm{rpm}$ and $2 \mathrm{vvm}$ aeration rate (Lee et al., 2000; Oh et al., 2013). The bioreactor was equipped with a condenser cooled with water to prevent evaporation. The $\mathrm{pH}$-value of 5 was automatically adjusted by addition of $\mathrm{NaOH}(5 \mathrm{M})$ or $\mathrm{HCl}(5 \mathrm{M})$ solutions. After glucose in the medium was completely depleted, a glucose stock solution of $300 \mathrm{~g} / \mathrm{L}$ was continuously fed at a flow rate of $4.8 \mathrm{~mL} / \mathrm{h}$. Samples were withdrawn at desired times and stored at $4{ }^{\circ} \mathrm{C}$ after centrifugation for further analysis of sugars (glucose and xylose) and xylitol and ethanol. Biomass concentration in the media was measured by dry cell weight.

\subsection{Corn cob hydrolysate: autohydrolysis pretreatment}

Corn cob was collected, milled and submitted to hydrothermal treatment (autohydrolysis) under non-isothermal conditions $\left(\mathrm{T}_{\max }\right.$ of $205^{\circ} \mathrm{C}$, corresponding to a severity of 3.85 ) based of previous works (Garrote et al., 2008; Rivas et al., 2006) in a $2 \mathrm{~L}$ stainless steel reactor (Parr Instruments Company) equipped with Parr PDI temperature controller (model 4848) at liquid to solid ratio of $8 \mathrm{~g}$ distilled water $/ \mathrm{g}$ of corn cob oven dry. After treatment, the resulting solid and liquid phases (whole slurry) were separated by filtration. Solid phase (pretreated corn cob) was recovered and washed for Solid Yield (SY) determination. Corn cob and pretreated corn cob were analysed for chemical composition following standard methods described by NREL protocols (NREL/TP-510-42618-42622-4218). Composition of hydrolysates (sugars, acetic acid and furan compounds) was analysed by HPLC.

\subsection{Enzymatic saccharification of pretreated corn cob}

Enzymatic saccharification of pretreated corn cob was carried out at $30{ }^{\circ} \mathrm{C}, 200 \mathrm{rpm}$ in an orbital shaker using a percentage of solids of 5 and $10 \%$ at different enzyme loadings (6,12 and $24 \mathrm{FPU} / \mathrm{g}$ ). Enzyme used in these assays was Cellic CTec2 (kindly supplied by Novozymes, Bagsvaerd, Denmark). Cellulase and hemicellulase activities of Cellic $\mathrm{CTec} 2$ were $122 \mathrm{FPU} / \mathrm{mL}$ and $9764 \mathrm{U} / \mathrm{mL}$, determined following the procedure described by (Ghose, 1987) and (Bailey et al., 1992), respectively. Samples were withdrawn and analysed by HPLC to determine the glucose and xylose concentration and glucose yield from experiments. Glucose yield was calculated following the equation:

Glucose yield $(\%)=\frac{G}{\frac{180}{162} f B} 100$ where, $G$ is glucose concentration $(\mathrm{g} / \mathrm{L}), B$ is dry corn cob biomass concentration $(\mathrm{g} / \mathrm{L}), f$ is glucan fraction in dry biomass ( $\mathrm{g}$ per $\mathrm{g}$ ), 180/ 162 is the stoichiometric factor that converts glucan to equivalent glucose.

\subsection{Presaccharification and simultaneous saccharification and fermentation (PSSF and SSF) assays of corn cob whole slurry}

Simultaneous saccharification and fermentation (SSF) assays were carried out in $250 \mathrm{~mL}$ Erlenmeyer flasks (working volume $40 \mathrm{~mL}$ ) at $30^{\circ} \mathrm{C}$ and $200 \mathrm{rpm}$ in an orbital shaker, using both solid and liquid phases (whole slurry) from corn cob autohydrolysis as substrates. Autohydrolyzed solid phase (pretreated corn cob) was sterilized at $121^{\circ} \mathrm{C}$ for $20 \mathrm{~min}$, whereas the liquid phase (corn cob hydrolysate) was subjected to a second step of acid hydrolysis with $0.5 \%$ (w/w) $\mathrm{H}_{2} \mathrm{SO}_{4}$ for $165 \mathrm{~min}$ at $125^{\circ} \mathrm{C}$ (Rivas et al., 2006). The obtained hydrolysates, enriched in xylose, were neutralized with $\mathrm{CaCO}_{3}$ until pH 5 and sterilized by filtration $(0.2 \mu \mathrm{m})$ and aseptically added to autoclaved solid fraction. SSF assays were carried out using 5\% solids at 6 and $12 \mathrm{FPU} / \mathrm{g}$. Presaccharification and simultaneous saccharification and fermentation (PSSF) assays were carried out in $250 \mathrm{~mL}$ Erlenmeyer flasks ( $40 \mathrm{~mL}$ of working volume) and in a $3.7 \mathrm{~L}$ Bioengineering's RALF bioreactor $(1.5 \mathrm{~L}$ of working volume). Enzymatic saccharification stage of whole slurry (solid and liquid phases) was carried out for $24 \mathrm{~h}$ using 5 or $10 \%$ solids at 12 or $24 \mathrm{FPU} / \mathrm{g}$. During these PSSF experiments, fed-batch of $5 \%$ solids (supplemented with respective enzyme loading) was conducted to further feed glucose. Fig. 2 shows a schematic representation of corn cob processing for xylitol production carried out in this work.

\subsection{Analytical methods}

Samples from corn cob analysis, autohydrolysis treatment of corn cob (hydrolysate and pretreated corn cob) and from fermentation assays were analysed for quantification of sugars (glucose, xylose, arabinose), acetic acid, xylitol, furfural, hydroxymethylfurfural (HMF) and ethanol by HPLC utilizing a BioRad Aminex HPX-87H $(300 \times 7.8 \mathrm{~mm})$ column, at $60{ }^{\circ} \mathrm{C}$, using $0.005 \mathrm{M}$ sulfuric acid as eluent in a flow rate $0.6 \mathrm{~mL} / \mathrm{min}$. The peaks corresponding to sugars, acetic acid, xylitol and ethanol were detected using a Knauer-IR intelligent refractive index detector, whereas furfural and HMF were detected using a Knauer-UV detector set at $280 \mathrm{~nm}$.

\subsection{Determination of fermentation parameters}

Metabolic yield of xylitol from xylose $\left(\mathrm{Y}_{\mathrm{XL}} / \mathrm{xy}\right)$ was defined as $\mathrm{g}$ of xylitol produced/g of xylose consumed. Biomass yield $\left(\mathrm{Y}_{\mathrm{X} / \mathrm{S}}\right)$ was expressed as $\mathrm{g}$ of dry cell/g of glucose consumed. The xylitol productivity $\left(\mathrm{Qp}_{\mathrm{t}}, \mathrm{g} / \mathrm{L} \mathrm{h}\right)$ was calculated as follows:

$Q p_{t}=\frac{[X L]_{t}}{t}$

where $[\mathrm{XL}]$ is xylitol concentration at time $t$ divided by time $\mathrm{t}$.

\section{Results and discussion}

\subsection{Evaluation of strains for xylitol production in batch fermentation}

Several factors interfering with the xylitol production have already been identified, such as specific XR activity, transport of xylose into the cell and generation of reduced cofactors (Meinander and HahnHägerdal, 1997). In this sense, the recombinant strains PE-2-XR mut $_{\text {, }}$ PE$2-\mathrm{XR}_{\mathrm{wt}}$ and PE-2-GRE3, expressing different xylose/aldose reductases, were compared in terms of xylitol production (Fig. 3, Table 2).

Considering that xylose is not naturally consumed by $S$. cerevisiae, the recombinant strains need a carbon source for cell growth and cofactors regeneration (Hallborn et al., 1991). Therefore, to evaluate the 


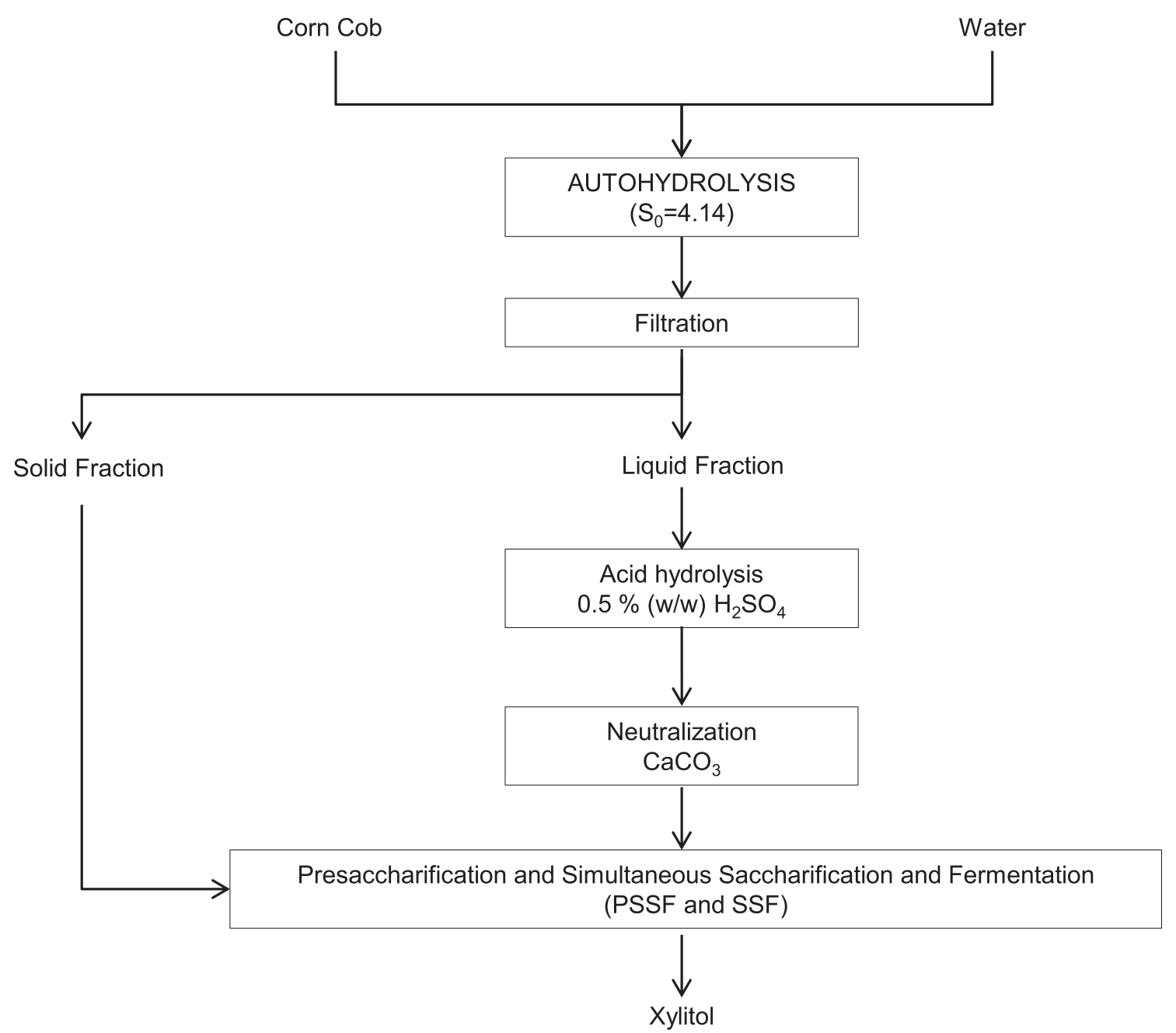

Fig. 2. Flowchart of main steps involved in the corn cob to xylitol process.

xylose consumption and the xylitol production patterns for the different strains, aerobic batch fermentations were performed on medium containing glucose and xylose (Fig. 3, Table 2). In yeast, xylose uptake occurs by facilitated diffusion through the hexose uptake systems (Hamacher et al., 2002), being competitively inhibited by glucose (Subtil and Boles, 2012). Accordingly, all strains showed xylose uptake only after a considerable decrease in glucose concentration for all tested strains (Fig. 3). After glucose depletion, the ethanol produced during the cultivations was re-assimilated and used as co-substrate for cofactors regeneration by yeast, allowing further xylitol production. Although the cell mass production was similar in all experiments $(\sim 20 \mathrm{~g} /$ $\mathrm{L}$ at $48 \mathrm{~h}$ ), xylose was converted into xylitol at different rates by the

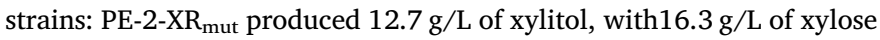
remaining in the medium (Fig. 3a); while the PE-2-XR ${ }_{\mathrm{wt}}$ and PE-2-GRE3 strains produced 24.2 and $27.8 \mathrm{~g} / \mathrm{L}$ of xylitol, respectively, by conversion of almost all xylose present in the media (Fig. 3b and c). The xylitol yield attained by PE-2-XR $\mathrm{wt}_{\mathrm{wt}}$ and PE-2-GRE3 was close to the theoretical (Table 2), however PE-2-GRE3 consumed xylose considerably faster and produced higher amounts of xylitol $(28 \mathrm{~g} / \mathrm{L})$ with a superior productivity of $0.54 \mathrm{~g} / \mathrm{L} \cdot \mathrm{h}$ at $48 \mathrm{~h}$. Both strains PE-2-XR $\mathrm{wt}_{\mathrm{wt}}$ and PE-2-GRE3 express an enzyme with higher specificity for NADPH (Kuhn et al.,

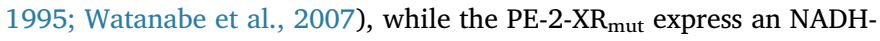
preferable xylose reductase enzyme. It is well known that the pentose phosphate pathway (PPP), an essential metabolic pathway in the glucose metabolism, is a major source of NADPH (Bruinenberg et al., 1983), and in this case, the use of glucose as co-substrate may result in a superior performance of the strains expressing enzymes with NADPH preference. Furthermore, the fact that $\mathrm{XR}_{\mathrm{wt}}$ is capable of using both NADH and NADPH, while the aldose reductase encoded by GRE3 uses solely NADPH, may explain the higher production of xylitol by the PE2-GRE3 strain. Accordingly, the xylitol production from a GRE3-overexpressing $S$. cerevisiae strain, was already described as a better strategy for xylitol production, in comparison with the expression of XR of $P$. stipitis, in the presence of glucose as co-substrate (Kogje and Ghosalkar, 2016). In fact, the use of different co-substrates could result in different mechanisms of co-factors regeneration and consequently different responses by the enzymes. Another study of comparison of $S$. cerevisiae strains harboring XYL1 gene of $P$. stipitis or overexpressing GRE3 gene, using ethanol as co-substrate, reported a superior xylitol production by the recombinant strain expressing the XR, justified by a higher regeneration of NADH during ethanol oxidation to acetate and subsequent metabolization in the TCA cycle (Kim et al., 2002).

CEN.PK 113-5D-GRE3 was used as control to confirm the advantage of using as chassis a natural xylitol accumulating background (Costa et al., 2017; Romani et al., 2015), and despite having consumed more than $90 \%$ of xylose in the medium, only produced $19.1 \mathrm{~g} / \mathrm{L}$ of xylitol. Besides and as expected, this laboratorial strain exhibits a slower carbon source consumption (glucose and ethanol) and consequently, a lower yield $(0.68 \mathrm{~g} / \mathrm{g})$ and xylitol productivity $(0.22 \mathrm{~g} / \mathrm{L} \cdot \mathrm{h})$ when comparing to the high-rate glucose-consuming industrial PE-2 strain (Pereira et al., 2010). Moreover, additional process advantages are expected when using PE-2 as chassis, namely the tolerance to inhibitors present in hydrolysates (Pereira et al., 2014) that enable the use of nondetoxified hydrolysates simplifying significantly the overall process. 

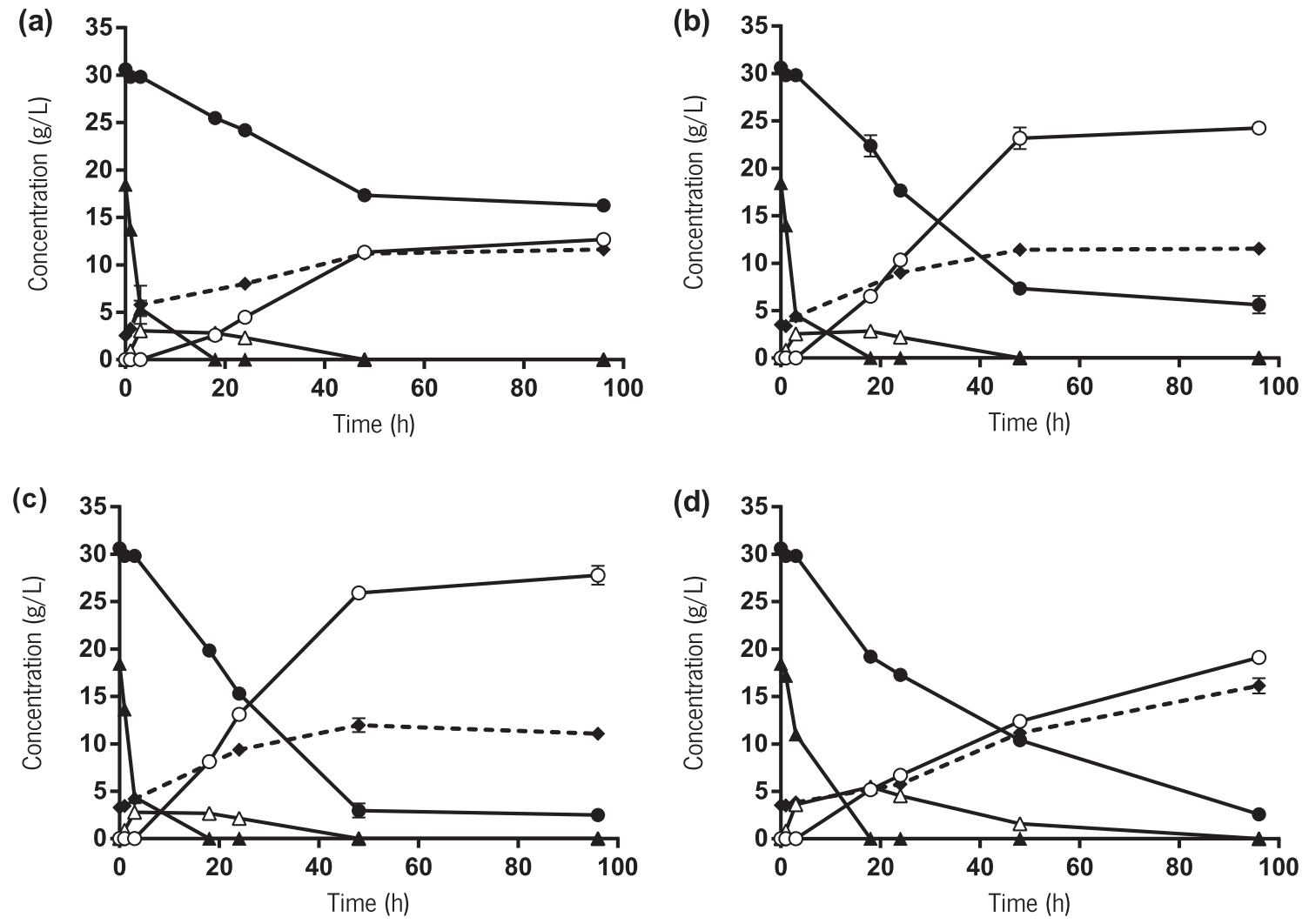

\section{Xylose $-0-$ Xylitol $\leftarrow$ Glucose $₫$ Ethanol $\bullet$ DCW}

Fig. 3. Performance of the $S$. cerevisiae (a) PE-2-XR $\mathrm{mut}_{\mathrm{mu}}$, (b) PE-2-XR $\mathrm{wt}_{\mathrm{wt}}$, (c) PE-2-GRE3 and (d) CEN.PK 113-5D-GRE3 by the time course of xylose and glucose consumption as well as xylitol and ethanol production.

\subsection{Fed-batch fermentations}

As observed in the batch fermentations (Section 3.1.), bioconversion stops when the carbon source is depleted, probably due to the lack of reducing power. In this way, to maintain co-factor regeneration and yeast metabolism without catabolite repression of xylose uptake, a glucose-limited fed-batch fermentation strategy has been previously applied for enhancement of xylitol productivity (Bae et al., 2004; Chung et al., 2002; Govinden et al., 2001; Kogje and Ghosalkar, 2016; Lee et al., 2000; Meinander and Hahn-Hagerdal, 1997; Meinander and Hahn-Hägerdal, 1997). Considering that high xylose concentrations may pose as another limitation for xylitol production, the limited- glucose fed-batch strategy was used in bioreactor to evaluate PE-2GRE3 xylitol productivity from increasing concentrations of initial xylose (64.6, 126 and 159 g/L) (Fig. 4, Table 2). To attain higher yeast biomass and increase xylitol productivity all fermentations were firstly conducted in batch mode until depletion of the initial $30 \mathrm{~g} / \mathrm{L}$ of glucose; which was followed by a continuous feeding of low glucose concentrations. The ethanol formed in the batch growth phase remained constant during the fed-batch xylitol production phase while biomass growth was observed even though at a slower rate. In these fed-batch assays, the maximum dry cell mass achieved was of $34.7 \mathrm{~g} / \mathrm{L}$ (Fig. 4c). In addition, no glucose was detected in the broth during this phase, indicating that glucose gradually supplied was instantly consumed by

Table 2

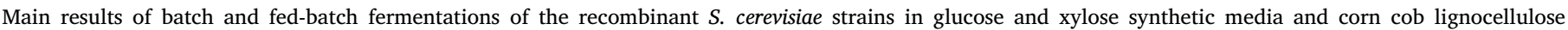
hydrolysate (Fed-Batch 4).

\begin{tabular}{|c|c|c|c|c|c|c|}
\hline Culture & S. cerevisiae strains & $\mathrm{Xy}_{\mathrm{to}}(\mathrm{g} / \mathrm{L})$ & $\mathrm{Xy}_{\mathrm{tf}}(\mathrm{g} / \mathrm{L})$ & Xyol $_{\mathrm{tf}}(\mathrm{g} / \mathrm{L})$ & $\mathrm{Y}_{\mathrm{Xyol} / \mathrm{Xy}}(\mathrm{g} / \mathrm{g})$ & $\mathrm{Q}_{\text {pmax }}(\mathrm{g} / \mathrm{L} \cdot \mathrm{h})$ \\
\hline \multicolumn{7}{|l|}{ Batch } \\
\hline 1 & $\mathrm{PE}-2-\mathrm{XR}_{\mathrm{mut}}$ & $30.6 \pm 0.8$ & $16.3 \pm 0.4$ & $12.7 \pm 0.1$ & $0.88 \pm 0.03$ & $0.24 \pm 0.01$ \\
\hline 2 & $\mathrm{PE}-2-\mathrm{XR}_{\mathrm{wt}}$ & $30.6 \pm 0.8$ & $5.62 \pm 1.30$ & $24.2 \pm 0.6$ & $0.97 \pm 0.03$ & $0.48 \pm 0.03$ \\
\hline 3 & PE-2-GRE3 & $30.6 \pm 0.8$ & $2.57 \pm 0.01$ & $27.8 \pm 1.4$ & $0.99 \pm 0.04$ & $0.54 \pm 0.00$ \\
\hline 4 & CEN.PK 113-5D-GRE3 & $30.6 \pm 0.8$ & $2.60 \pm 0.55$ & $19.1 \pm 0.4$ & $0.68 \pm 0.00$ & $0.22 \pm 0.01$ \\
\hline \multicolumn{7}{|c|}{ Fed-Batch } \\
\hline 1 & PE-2-GRE3 & $64.6 \pm 0.92$ & $0.86 \pm 0.73$ & $62.4 \pm 0.02$ & $0.98 \pm 0.00$ & $1.44 \pm 0.23$ \\
\hline 2 & PE-2-GRE3 & $126 \pm 5.1$ & $1.51 \pm 0.09$ & $121.1 \pm 3.59$ & $0.98 \pm 0.01$ & $1.56 \pm 0.15$ \\
\hline 3 & PE-2-GRE3 & $159 \pm 2.08$ & $2.52 \pm 0.13$ & $148.5 \pm 4.02$ & $0.95 \pm 0.01$ & $1.16 \pm 0.08$ \\
\hline 4 & PE-2-GRE3 & $27.2 \pm 0.01$ & $5.71 \pm 0.01$ & $19.0 \pm 0.01$ & $0.89 \pm 0.00$ & $0.39 \pm 0.01$ \\
\hline
\end{tabular}

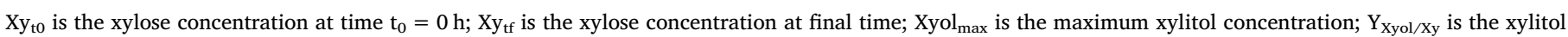
yield from xylose consumed; $\mathrm{Q}_{\mathrm{pmax}}$ is the maximum productivity achieved in the assays. 
(a)

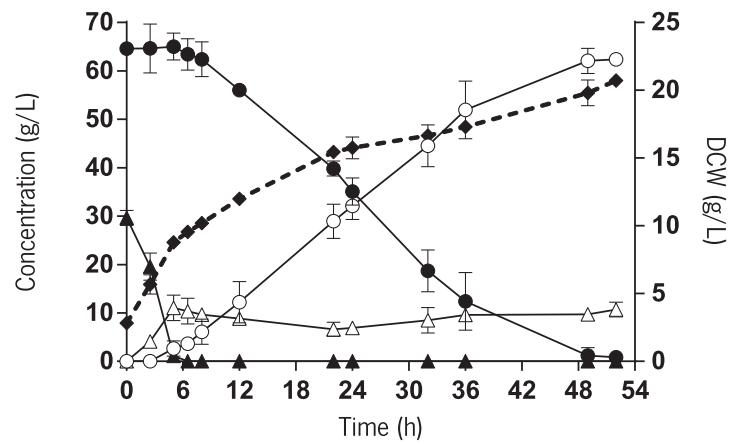

(c)

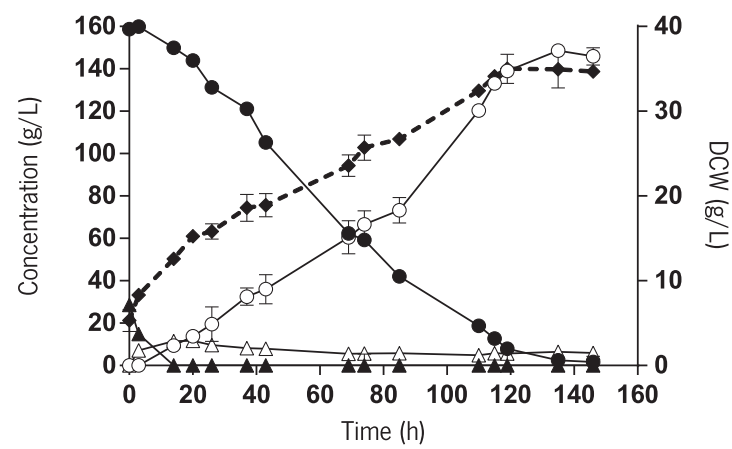

(b)

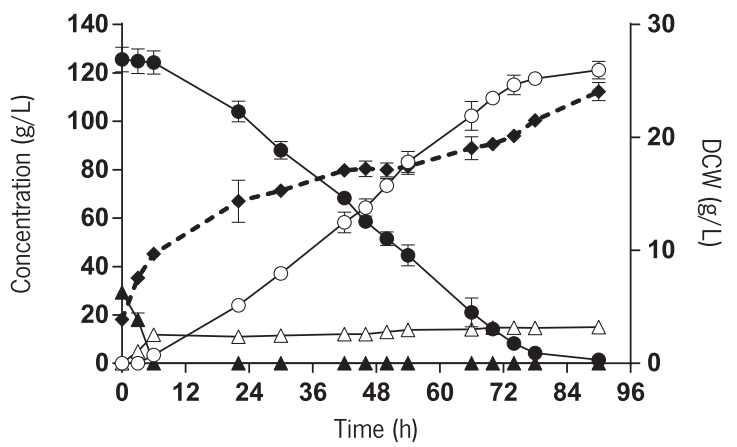

(d)

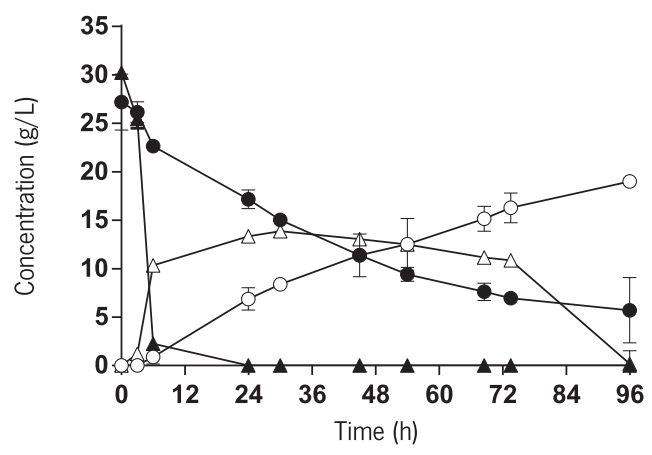

Glucose $\triangle$ Ethanol

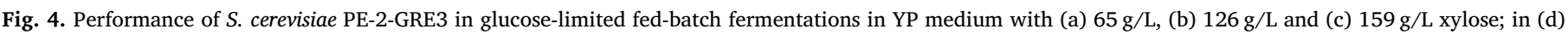

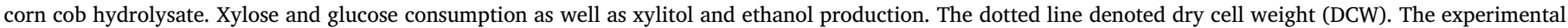
results were revised for the effects of dilution and sampling on the broth volume.

the yeast. After starting the glucose feed, xylose uptake occurred at constant rate (reaching nearly xylose depletion) and xylitol was produced close to theoretical yields in all the experiments, with $62.4,121.1$ and $148.5 \mathrm{~g} / \mathrm{L}$ of xylitol being produced from $64.6,126$ and $159 \mathrm{~g} / \mathrm{L}$ of initial xylose, respectively (Fig. 4). Furthermore, and despite some variation, xylitol productivity does not seem to be diminished by high initial xylose concentrations (Table 2), indicating that there are no saturation of xylose transporter system and no substrate inhibition of the xylose reductase activity.

The xylitol production obtained with this strategy is in the upper range of previous works using recombinant $S$. cerevisiae strains. Oh et al. (2013) with an engineered $S$. cerevisiae for co-utilization of xylose and cellobiose attained $93 \mathrm{~g} / \mathrm{L}$ of xylitol. Some studies describe a gradual addition of xylose to the culture medium in order to increase xylitol productivity. In fact, Lee et al. (2000), with a recombinant $S$. cerevisiae expressing a xylose reductase from $P$. stipitis, obtained $105 \mathrm{~g} / \mathrm{L}$ of xylitol with a productivity of $1.69 \mathrm{~g} / \mathrm{L} \cdot \mathrm{h}$, maintaining a low substrate concentration using a fed-batch strategy with simultaneous addition of xylose and glucose during the bioconversion phase. More recently, Kim et al. (2017) achieved high xylitol productivity in a glucose-limited fedbatch culture with pulsed addition of xylose, producing a maximum of $178 \mathrm{~g} / \mathrm{L}$ of xylitol. Nevertheless, it should be noted that the strain used expresses the arabinose $\mathrm{H}+$ symporter (AraE) from Bacillus subtilis, in addition to the XYL1 gene from Scheffersomyces stipitis, which substantially increases xylose uptake (Kim et al., 2017).

In comparison, the PE-2 strain presented in this work, with the sole overexpression of GRE3, withstands high substrate loading, efficiently converting high values of initial xylose into xylitol, and presents similar productivities to the ones attained with lower xylose concentrations or with modifications in the yeast xylose uptake system (Kim et al., 2017; Lee et al., 2000; Oh et al., 2013).

\subsubsection{Hydrothermal treatment of corn cob: hemicellulosic hydrolysate}

The use of renewable and low cost raw materials as lignocellulosic biomass (including agricultural and forest residues) is mandatory to develop a sustainable bioprocess for xylitol production (Dasgupta et al., 2017; Venkateswar Rao et al., 2016). In this sense, corn cob was selected for its high xylan content (Irmak et al., 2017; Rivas et al., 2002; Ruiz et al., 2013; Venkateswar Rao et al., 2016). The chemical composition of corn cob (expressed in $\mathrm{g} / 100 \mathrm{~g}$ wood in oven-dry basis \pm standard deviation based on three replicate determinations) was: $30.89 \% \pm 0.45$ of xylan, $27.32 \% \pm 0.24$ of glucan, $22.92 \% \pm 0.84$ of Klason lignin, $3.52 \% \pm 0.22$ of arabinan, $2.15 \% \pm 0.03$ of acetyl groups and $6.05 \% \pm 0.22$ of extractives. The complex and recalcitrant structure of lignocellulosic materials hinder the access to monomeric sugars (Romaní et al., 2010a). Hydrothermal treatment (also known as autohydrolysis or liquid hot water) followed by dilute acid treatment has been extensively used for the enhancement of cellulose saccharification (Garrote et al., 2008; Romaní et al., 2010b) and to obtain hemicellulosic hydrolysate enriched in xylose (Rivas et al., 2002; Rodríguez-López et al., 2012; Romani et al., 2015). The operational conditions of corn cob processing were selected based on literature (Garrote et al., 2008; Rivas et al., 2002). The solid phase was recovered for the solid yield $(56.2 \pm 0.02)$ determination. Chemical composition of solid phase (expressed in $\mathrm{g} / 100 \mathrm{~g}$ of pretreated corn cob in oven-dry basis \pm standard deviation based on three replicate determinations) was: $39.63 \% \pm 0.75$ of glucan, $15.05 \% \pm 0.45$ of xylan, $38.33 \% \pm 0.88$ of Klason lignin and $0.31 \% \pm 0.01$ of arabinan. After 
autohydrolysis treatment, $81.5 \%$ of cellulose (measured as glucan) and $27.2 \%$ of xylan were recovered in the solid phase. On the other hand, composition of hemicellulosic hydrolysate was as follow: $2.25 \pm 0.00 \mathrm{~g} / \mathrm{L}$ of glucose, $27.82 \pm 0.38 \mathrm{~g} / \mathrm{L}$ of xylose, $3.11 \pm 0.00 \mathrm{~g} / \mathrm{L}$ of arabinose, $2.83 \pm 0.00 \mathrm{~g} / \mathrm{L}$ of acetic acid, $1.09 \pm 0.27 \mathrm{~g} / \mathrm{L}$ of furfural and $0.04 \pm 0.03 \mathrm{~g} / \mathrm{L}$ of HMF. Therefore, $68.2 \%$ of xylan was solubilized and recovered in the liquid phase (or hemicellulosic hydrolysate) as xylose, after acid hydrolysis of the autohydrolysis liquor. The hemicellulosic hydrolysate was composed mainly by xylose $(28 \mathrm{~g} / \mathrm{L})$ and acetic acid $(2.88 \mathrm{~g} / \mathrm{L})$, and its composition was similar to the one reported by Rivas et al. (2002) for sequential stages of autohydrolysis and dilute acid posthydrolysis of corn cob autohydrolysis liquor.

Hemicellulosic hydrolysates obtained from different lignocellulosic biomass (such corn cob, wheat straw, rapeseed straw, breweŕs spent grain) are the most commonly renewable substrates used for xylitol production (Kumar et al., 2018; López-Linares et al., 2018; Venkateswar Rao et al., 2016). Generally, hemicellulosic hydrolysates for xylitol production are submitted to costly steps of detoxification to improve the fermentation process since most yeast have low tolerance towards inhibitory compounds, such as acetic acid, furfural and HMF (López-Linares et al., 2018; Pereira et al., 2014). In this work, non-detoxified corn cob hydrolysate was used as substrate for xylitol production by the inhibitor-tolerant engineered PE-2-GRE3 strain, under conditions described for the bioreactor assays using synthetic media (Fig. 4a-c). Initial glucose was consumed within $10 \mathrm{~h}$ of fermentation and $15 \mathrm{~g} / \mathrm{L}$ of ethanol was produced from glucose consumed (Fig. 4d). After glucose depletion, hemicellulosic hydrolysate was supplemented with glucose in fed-batch mode. As expected, the xylitol productivity in hemicellulosic hydrolysate (Table 2, fed-batch 4) was lower in comparison with productivities obtained in synthetic media, probably due to the presence of inhibitors such as furfural, HMF and acetic acid that have a negative effect on yeast growth (Perez-Bibbins et al., 2014). As seen in Fig. 4d, $74 \%$ of xylose was consumed at $72 \mathrm{~h}$ of fermentation with a maximal xylitol production of $17.5 \mathrm{~g} / \mathrm{L}$, corresponding to a xylitol yield of $0.89 \mathrm{~g} / \mathrm{g}$. These results can be positively compared with the one obtained by a natural xylitol-producing Candida tropicalis strain from a non-detoxified hydrolysate, added in fed-batch mode, with a reported yield of 0.7 (Ping et al., 2013). A fed-batch strategy similar to the one used in this work was also proposed by Kogje and Ghosalkar (2017) for xylitol production using a recombinant $S$. cerevisiae XPRTK strain (overexpressing GRE3 and a xylose specific transporter from $P$. stipitis), which produced $16 \mathrm{~g} / \mathrm{L}$ of xylitol from non-detoxified but diluted corn cob hydrolysate with a maximal productivity of $0.21 \mathrm{~g} / \mathrm{L} \cdot \mathrm{h}$.

\subsection{Simultaneous saccharification and fermentation assays of pretreated corn cob for xylitol production}

In order to develop an integrated and sustainable process, the solid phase obtained from the autohydrolysis pretreatment and mainly composed by glucan (39.6\%) was proposed as co-substrate to supplement glucose for xylose bioconversion into xylitol. Cellulose saccharification of pretreated corn cob for glucose release aims to mimic glucose supplementation in fed-batch mode to keep a basal level of glucose supply. For that, different percentage of solids (5 and 10\%) and enzyme loadings $(6,12$ and $24 \mathrm{FPU} / \mathrm{g}$ ) were assayed to evaluate the glucose release by enzymatic hydrolysis. Fig. 5a presents the glucose profile obtained from saccharification of pretreated corn cob biomass. As seen, glucose concentration varied in the range of $6.9-32.9 \mathrm{~g} / \mathrm{L}$, corresponding to experiments at $6 \mathrm{FPU} / \mathrm{g}$ and $5 \%$ of solids and $24 \mathrm{FPU} / \mathrm{g}$ and $10 \%$ of solids, respectively. Xylose released from the solid by enzymatic saccharification was also quantified (data no shown) achieving concentrations in the range of 3.36-6.25 g/L. Glucose yields of enzymatic saccharification assays are shown in Fig. $5 \mathrm{~b}$ and varied from 32.4 to
$78.8 \%$. The glucose concentration and glucose yield were significantly influenced by the increase of enzyme loading. Considering that glucose at high concentration limits xylose uptake by yeast (Oh et al., 2013), the use of $5 \%$ of solid (Fig. 5a) seemed more suitable to maintain a low level of glucose thus to and improve xylitol yield and productivity. Moreover, a previous study using pretreated corn cob (only the solid fraction resultant from alkali pretreatment) for xylitol production by SSF revealed higher yields when using a 5\% solid loading (Latif and Rajoka, 2001). Fig. 6a-b shows the SSF assays carried out for xylose bioconversion into xylitol using 6 and $12 \mathrm{FPU} / \mathrm{g}$. As seen, SSF carried out with $6 \mathrm{FPU} / \mathrm{g}$ showed an incomplete xylose consumption (54.19\%) and a xylitol production of $14.13 \mathrm{~g} / \mathrm{L}$ (Table 3 ). Under this condition, the glucose released during enzymatic hydrolysis was not sufficient to allow the complete conversion of xylose into xylitol. On the other hand, the SSF assay at $12 \mathrm{FPU} / \mathrm{g}$ and $5 \%$ of pretreated corn cob (Fig. 6b) showed a xylose consumption of $89.9 \%$ with a xylitol production of $23.2 \mathrm{~g} / \mathrm{L}$ which corresponded to $0.91 \mathrm{~g} / \mathrm{g}$ of xylitol yield (Table 3 ). The increase of enzyme loading allowed a higher cellulose saccharification which improved the xylitol production (1.64 fold higher than xylitol produced by SSF at $6 \mathrm{FPU} / \mathrm{g}$ ). Xylitol yield in this condition was also considerably higher than others reported for an SSF of the solid fraction of an alkali pretreated corn cob using $S$. cerevisiae and $C$. tropicalis strains $(0.71 \mathrm{~g} / \mathrm{g}$ by C. tropicalis, $0.52 \mathrm{~g} / \mathrm{g}$ by $S$. cerevisiae and $0.69 \mathrm{~g} / \mathrm{g}$ in co-culture) (Latif and Rajoka, 2001).

A saccharification step before the SSF process, also known as Presaccharification and simultaneous saccharification and fermentation (PSSF), is proposed as an alternative strategy for xylitol production from whole slurry of corn cob. This strategy aims to mimic the conditions used for xylitol production from synthetic media (Section 3.2), where the initial glucose concentration is used for yeast biomass growth aiming an increase in xylitol productivity. Fig. $6 \mathrm{c}$ shows glucose production during the pre-saccharification step $(9 \mathrm{~g} / \mathrm{L})$. After this stage, yeast cells were added and glucose was rapidly consumed $(<3 \mathrm{~h})$ resulting in the maximal ethanol production of $4.8 \mathrm{~g} / \mathrm{L}$. At $30 \mathrm{~h}$ and $54 \mathrm{~h}$, PSSF assay was supplemented with $5 \%$ of solid loading (pretreated corn cob) in order to maintain a glucose feed during the bioconversion process of xylose into xylitol. In this experiment, 79.9\% of xylose was consumed at $96 \mathrm{~h}$ of PSSF process and maximal xylitol concentration of $29.6 \mathrm{~g} / \mathrm{L}$ with a xylitol yield of $0.93 \mathrm{~g} / \mathrm{g}$ was achieved (Table 3). Xylitol productivity (not considering the $24 \mathrm{~h}$ of pre-saccharification) achieved a maximal value of $0.54 \mathrm{~g} / \mathrm{Lh}$, being slightly lower than the maximal productivity obtained in SSF-2 $(0.74 \mathrm{~g} / \mathrm{Lh})$. Nevertheless, xylitol production was increased compared to SSF-2 experiment (Table 3), reaching $27 \%$ higher xylitol concentration. This increase is caused by the addition of xylan-containing solid at different times of PSSF, resulting in a proportional increase of available xylose for conversion.

As promising results were obtained from this strategy, the laboratory scale-up to a $3.7 \mathrm{~L}$ bioreactor was evaluated (PSSF-2, Fig. 6d). The initial percentage of pretreated corn cob was increased to $10 \%$ (Table 3), to achieve a higher concentration of initial glucose and consequently increase biomass growth, which resulted in the production of $25 \mathrm{~g} / \mathrm{L}$ of glucose in the $24 \mathrm{~h}$ of pre-saccharification step. After yeast addition, glucose was fermented into ethanol achieving a maximal concentration of $16.4 \mathrm{~g} / \mathrm{L}$. This unexpected high ethanol yield, which limits glucose use for yeast growth, was probably caused by the bioreactor design that may not be appropriate to work with a moderatehigh solid loading (15\%), hindering the oxygen mass transfer. Nevertheless, bioconversion of xylose into xylitol started at $28 \mathrm{~h}$. It should be noted that while xylitol concentration progressively increases after $28 \mathrm{~h}$, there seems to be a stabilization of xylose concentration in the medium up until $96 \mathrm{~h}$, which is explained by the gradual release of xylose (ca. $9.39 \mathrm{~g} / \mathrm{L}$ in total) from the xylan-containing solid loads. Even with the non-optimal conditions of solid load and aeration, more than $76 \%$ of available xylose was consumed in $96 \mathrm{~h}$, resulting in the production of $24.3 \mathrm{~g} / \mathrm{L}$ of xylitol with a yield of $0.88 \mathrm{~g} / \mathrm{g}$. Despite the need of additional optimization regarding bioreactor design, air flow 

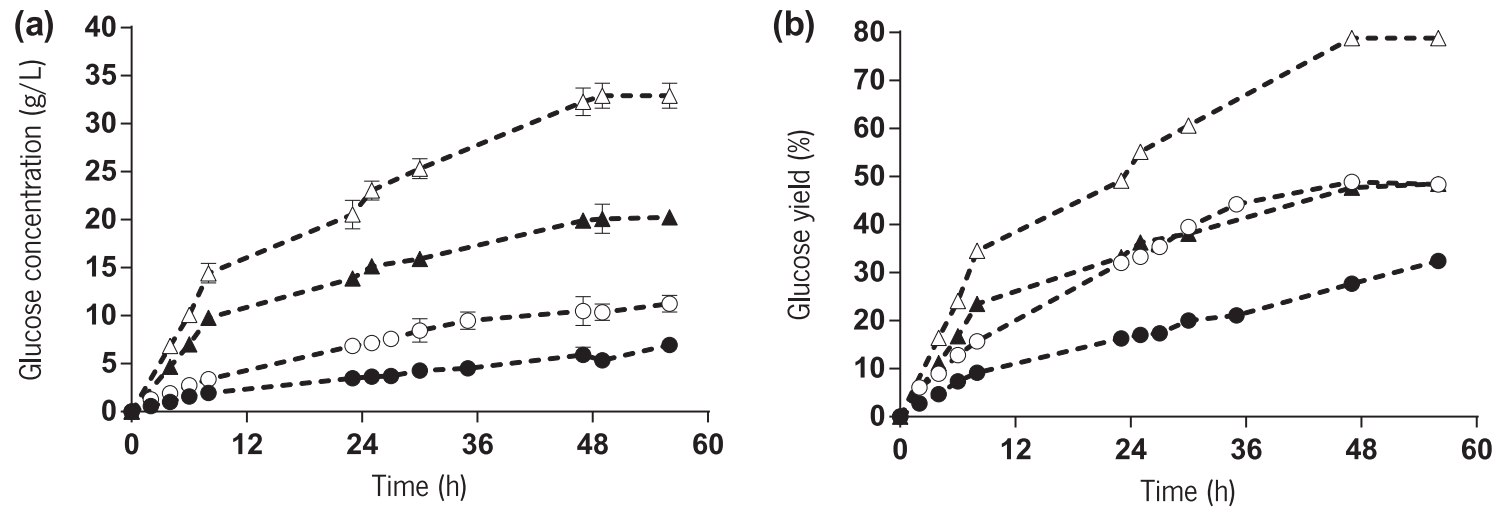

$$
\begin{aligned}
& \text {-๑ } 6 \mathrm{FPU} / \mathrm{g} \text { and } 5 \% \quad \text { - . } 12 \mathrm{FPU} / \mathrm{g} \text { and } 10 \% \\
& \text { - } \circ 12 \mathrm{FPU} \text { and 5\% - - } \quad 24 \mathrm{FPU} / \mathrm{g} \text { and } 10 \%
\end{aligned}
$$

Fig. 5. Time course of: (a) glucose concentration ( $\mathrm{g} / \mathrm{L})$ and (b) glucose yield (\%) in enzymatic saccharification experiments.
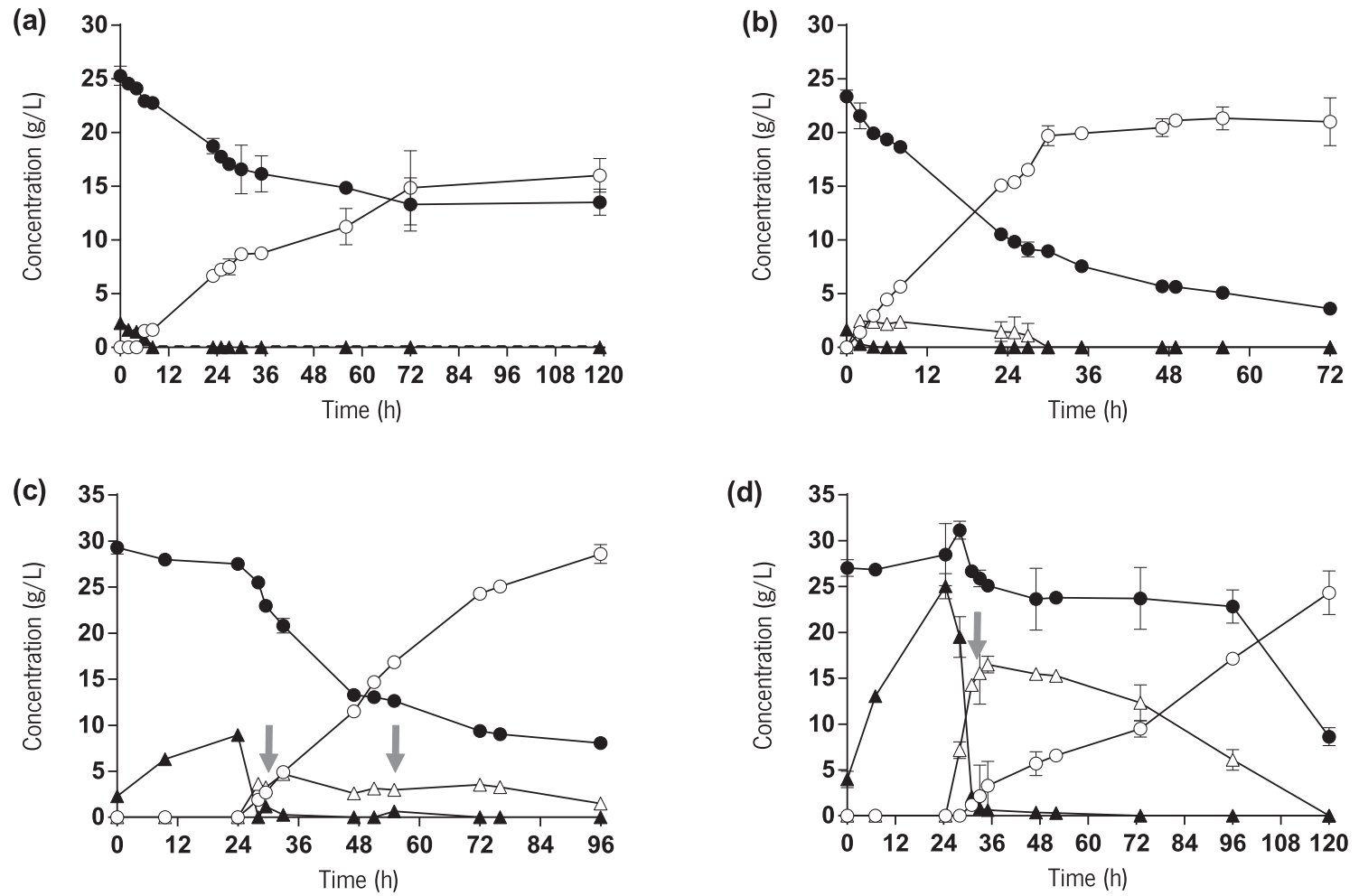

$$
\text { Xylose }-0-\text { Xylitol } \leftarrow \text { Glucose } \leftarrow \text { Ethanol }
$$

Fig. 6. Strategies for xylitol production from corn cob whole slurry by simultaneous saccharification and fermentation (SSF) process: (a) using 5\% of solid and $6 \mathrm{FPU} /$ $\mathrm{g}$ and (b) $5 \%$ of solid and $12 \mathrm{FPU} / \mathrm{g}$ and by presaccharification and simultaneous saccharification and fermentation (PSSF) process (added solid in fed-batch): (c) using $15 \%$ of solids and $12 \mathrm{FPU} / \mathrm{g}$ and (d) $15 \%$ and $20 \mathrm{FPU} / \mathrm{g}$ in bioreactor. Xylose and glucose consumption as well as xylitol and ethanol production. The arrows indicate the addition of solid.

and solid loading these results pave the way for the possibility of scaling-up xylitol production from lignocellulosic whole slurry envisioning an industrial scale.

\section{Conclusions}

This work shows that overexpressing the GRE3 endogenous gene in the robust and innate xylitol accumulation $S$. cerevisiae PE-2 strain enhances xylitol productivity when compared with expression of different xylose reductases in the same or different yeast chassis. In fed-batch fermentations, with limited-glucose feeding, the PE-2-GRE3 strain efficiently produce xylitol from remarkable high xylose concentrations. In addition, high yields of xylitol from non-detoxified corn cob hydrolysates were attained, in spite of the presence of inhibitory compounds. Furthermore, this work shows, for the first time, the feasibility of using whole slurry corn cob for xylitol production in a simultaneous saccharification process. 
Table 3

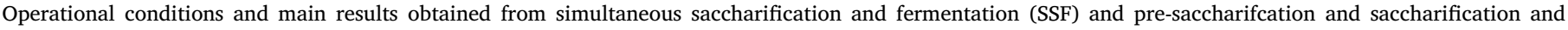
fermentation (PSSF) of corn cob whole slurry.

\begin{tabular}{|c|c|c|c|c|c|c|c|c|c|c|c|}
\hline \multirow{3}{*}{ Experiment } & \multicolumn{6}{|c|}{ Operational conditions } & \multicolumn{5}{|l|}{ Results } \\
\hline & \multicolumn{3}{|c|}{ Solid loading (\%) } & \multicolumn{3}{|c|}{ Enzyme load (FPU/g) } & \multirow[t]{2}{*}{$\operatorname{Xpot}^{*}(\mathrm{~g} / \mathrm{L})$} & \multirow[t]{2}{*}{ Xf $(g / L)$} & \multirow[t]{2}{*}{ Xylitol max (g/L) } & \multirow[t]{2}{*}{$\mathrm{Yp} / \mathrm{s}(\mathrm{g} / \mathrm{g})$} & \multirow[t]{2}{*}{ Qpmax $(\mathrm{g} / \mathrm{L} \cdot \mathrm{h})$} \\
\hline & $0 \mathrm{~h}$ & $30 \mathrm{~h}$ & $54 \mathrm{~h}$ & $0 \mathrm{~h}$ & $30 \mathrm{~h}$ & $54 \mathrm{~h}$ & & & & & \\
\hline \multicolumn{12}{|l|}{ Batch } \\
\hline SSF-1 & 5 & - & - & 6 & - & - & $30.58 \pm 0.87$ & $14.01 \pm 1.21$ & $14.13 \pm 0.87$ & $0.85 \pm 0.08$ & $0.30 \pm 0.01$ \\
\hline SSF-2 & 5 & - & - & 12 & - & - & $28.63 \pm 0.83$ & $3.14 \pm 0.67$ & $23.24 \pm 2.14$ & $0.91 \pm 0.11$ & $0.74 \pm 0.01$ \\
\hline \multicolumn{12}{|l|}{ Fed-batch } \\
\hline PSSF-1 & 5 & 5 & 5 & 12 & 12 & 12 & $39.81 \pm 0.97$ & $8.07 \pm 0.44$ & $29.61 \pm 1.43$ & $0.93 \pm 0.04$ & $0.54 \pm 0.01$ \\
\hline PSSF-2 & 10 & 5 & - & 24 & 12 & - & $36.41 \pm 0.90$ & $8.63 \pm 0.98$ & $24.32 \pm 2.37$ & $0.88 \pm 0.12$ & $0.30 \pm 0.02$ \\
\hline
\end{tabular}

* Xpot was calculated considering the sum of xylose concentration in the $t_{0}$ of SSF or PSSF with the xylose produced from xylan saccharification.

\section{Acknowledgements}

This study was supported by the Portuguese Foundation for Science and Technology (FCT, Portugal) under the scope of the strategic funding of UID/BIO/04469/2013 unit and COMPETE 2020 (POCI-010145-FEDER-006684/POCI-01-0145-FEDER-007440), the BioTecNorte operation (NORTE-01-0145-FEDER-000004) funded by European Regional Development Fund under the scope of Norte2020 - Programa Operacional Regional do Norte and the MultiBiorefinery project (POCI01-0145-FEDER-016403). Sara L. Baptista (SFRH/BD/132717) and Joana T. Cunha (PD/BD/128247/2016) thanks FCT and MIT-Portugal Program for their doctoral fellowships, respectively. We also thank Prof. Björn Johansson (University of Minho) for providing the p417 and p418 plasmids used in this study and the student Daniel Núñez for some of the experiments required for Fig. 3.

\section{References}

de Albuquerque, T.L., da Silva, I.J., de Macedo, G.R., Rocha, M.V.P., 2014. Biotechnological production of xylitol from lignocellulosic wastes: a review. Process Biochem. 49, 1779-1789.

Bae, S.-M., Park, Y.-C., Lee, T.-H., Kweon, D.-H., Choi, J.-H., Kim, S.-K., Ryu, Y.-W., Seo, J.-H., 2004. Production of xylitol by recombinant Saccharomyces cerevisiae containing xylose reductase gene in repeated fed-batch and cell-recycle fermentations. Enzyme Microb. Technol. 35, 545-549.

Bailey, M.J., Biely, P., Poutanen, K., 1992. Interlaboratory testing of methods for assay of xylanase activity. J. Biotechnol. 23, 257-270.

Basso, L.C., de Amorim, H.V., de Oliveira, A.J., Lopes, M.L., 2008. Yeast selection for fuel ethanol production in Brazil. FEMS Yeast Res. 8, 1155-1163. https://doi.org/10. 1111/j.1567-1364.2008.00428.x.

Bruinenberg, P.M., Van Dijken, J.P., Scheffers, W.a., 1983. A theoretical analysis of NADPH production and consumption in yeasts. Microbiology 129, 953-964. https:// doi.org/10.1099/00221287-129-4-953.

Budzianowski, W.M., 2017. High-value low-volume bioproducts coupled to bioenergies with potential to enhance business development of sustainable biorefineries. Renew. Sustain. Energy Rev. 70, 793-804.

Chung, Y.-S., Kim, M.-D., Lee, W.-J., Ryu, Y.-W., Kim, J.-H., Seo, J.-H., 2002. Stable expression of xylose reductase gene enhances xylitol production in recombinant Saccharomyces cerevisiae. Enzyme Microb. Technol. 30, 809-816. https://doi.org/ 10.1016/S0141-0229(02)00062-5.

Costa, C.E., Romani, A., Cunha, J.T., Johansson, B., Domingues, L., 2017. Integrated approach for selecting efficient Saccharomyces cerevisiae for industrial lignocellulosic fermentations: importance of yeast chassis linked to process conditions. Bioresour. Technol. 227, 24-34. https://doi.org/10.1016/j.biortech.2016.12.016.

Dasgupta, D., Bandhu, S., Adhikari, D.K., Ghosh, D., 2017. Challenges and prospects of xylitol production with whole cell bio-catalysis: a review. Microbiol. Res. 197, 9-21.

Garrote, G., Yáñez, R., Alonso, J.L., Parajó, J.C., 2008. Coproduction of oligosaccharides and glucose from corncobs by hydrothermal processing and enzymatic hydrolysis. Ind. Eng. Chem. Res. 47, 1336-1345. https://doi.org/10.1021/ie071201f.

Ghose, T.K., 1987. Measurement of cellulase activities. Pure Appl. Chem.

Gietz, R.D., Schiestl, R.H., 2007. High-efficiency yeast transformation using the LiAc/SS carrier DNA/PEG method. Nat. Protoc. 2, 31-34. https://doi.org/10.1038/nprot 2007.13.

Govinden, R., Pillay, B., van Zyl, W.H., Pillay, D., 2001. Xylitol production by recombinant Saccharomyces cerevisiae expressing the Pichia stipitis and Candida shehatae XYL1 genes. Appl. Microbiol. Biotechnol. 55, 76-80.

Guldener, U., Heck, S., Fielder, T., Beinhauer, J., Hegemann, J.H., 1996. A new efficient gene disruption cassette for repeated use in budding yeast. Nucleic Acids Res. 24,
2519-2524.

Hallborn, J., Walfridsson, M., Airaksinen, U., Ojamo, H., Hahn-Hagerdal, B., Penttila, M., Kerasnen, S., 1991. Xylitol production by recombinant Saccharomyces cerevisiae. Biotechnology (N.Y.) 9, 1090-1095.

Hamacher, T., Becker, J., Gardonyi, M., Hahn-Hagerdal, B., Boles, E., 2002. Characterization of the xylose-transporting properties of yeast hexose transporters and their influence on xylose utilization. Microbiology 148, 2783-2788. https://doi. org/10.1099/00221287-148-9-2783.

Irmak, S., Canisag, H., Vokoun, C., Meryemoglu, B., 2017. Xylitol production from lignocellulosics: are corn biomass residues good candidates? Biocatal. Agric. Biotechnol. 11, 220-223.

Isikgor, F.H., Becer, C.R., 2015. Lignocellulosic biomass: a sustainable platform for the production of bio-based chemicals and polymers. Polym. Chem. 6, 4497-4559. https://doi.org/10.1039/C5PY00263J.

Kim, H., Lee, H.-S., Park, H., Lee, D.-H., Boles, E., Chung, D., Park, Y.-C., 2017. Enhanced production of xylitol from xylose by expression of Bacillus subtilis arabinose:H+ symporter and Scheffersomyces stipitis xylose reductase in recombinant Saccharomyces cerevisiae. Enzyme Microb. Technol. 107, 7-14.

Kim, M.-D., Jeun, Y.-S., Kim, S.-G., Ryu, Y.-W., Seo, J.-H., 2002. Comparison of xylitol production in recombinant Saccharomyces cerevisiae strains harboring XYL1 gene of Pichia stipitis and GRE3 gene of S. cerevisiae. Enzyme Microb. Technol. 31, 862-866.

Kogje, A., Ghosalkar, A., 2016. Xylitol production by Saccharomyces cerevisiae overexpressing different xylose reductases using non-detoxified hemicellulosic hydrolysate of corncob. 3 Biotech 6.

Kogje, A.B., Ghosalkar, A., 2017. Xylitol production by genetically modified industrial strain of Saccharomyces cerevisiae using glycerol as co-substrate. J. Ind. Microbiol.Biotechnol. 44, 961-971. https://doi.org/10.1007/s10295-017-1914-3.

Kuhn, A., van Zyl, C., van Tonder, A., Prior, B.A., 1995. Purification and partial characterization of an aldo-keto reductase from Saccharomyces cerevisiae. Appl. Environ. Microbiol. 61, 1580-1585.

Kumar, V., Krishania, M., Preet Sandhu, P., Ahluwalia, V., Gnansounou, E., Sangwan, R.S., 2018. Efficient detoxification of corn cob hydrolysate with ion-exchange resins for enhanced xylitol production by Candida tropicalis MTCC 6192. Bioresour. Technol. 251, 416-419.

Latif, F., Rajoka, M.I., 2001. Production of ethanol and xylitol from corn cobs by yeasts. Bioresour. Technol. 77, 57-63.

Lee, W.-J.J., Ryu, Y.-W.W., Seo, J.-H.H., 2000. Characterization of two-substrate fermentation processes for xylitol production using recombinant Saccharomyces cerevisiae containing xylose reductase gene. Process Biochem. 35, 1199-1203. https:// doi.org/10.1016/S0032-9592(00)00165-5.

López-Linares, J.C., Romero, I., Cara, C., Castro, E., Mussatto, S.I., 2018. Xylitol production by Debaryomyces hansenii and Candida guilliermondii from rapeseed straw hemicellulosic hydrolysate. Bioresour. Technol. 247, 736-743.

Meinander, N.Q., Hahn-Hagerdal, B., 1997. Influence of cosubstrate concentration on xylose conversion by recombinant, XYL1-expressing Saccharomyces cerevisiae: a comparison of different sugars and ethanol as cosubstrates. Appl. Environ. Microbiol. 63, 1959-1964.

Meinander, N.Q., Hahn-Hägerdal, B., 1997. Fed-batch xylitol production with two recombinant Saccharomyces cerevisiae strains expressing XYL1 at different levels, using glucose as a cosubstrate: a comparison of production parameters and strain stability. Biotechnol. Bioeng. 54, 391-399. https://doi.org/10.1002/(SICI)10970290(19970520)54:4<391::AID-BIT12>3.0.CO;2-J.

Mohamad, N.L., Mustapa Kamal, S.M., Mokhtar, M.N., 2015. Xylitol biological production: a review of recent studies. Food Rev. Int. 31, 74-89. https://doi.org/10.1080/ 87559129.2014.961077.

Oh, E.J., Ha, S.J., Rin Kim, S., Lee, W.H., Galazka, J.M., Cate, J.H.D., Jin, Y.S., 2013. Enhanced xylitol production through simultaneous co-utilization of cellobiose and xylose by engineered Saccharomyces cerevisiae. Metab. Eng. 15, 226-234. https:// doi.org/10.1016/j.ymben.2012.09.003.

Pereira, F., Azevedo, F., Parachin, N.S., Hahn-Hagerdal, B., Gorwa-Grauslund, M.F., Johansson, B., 2016. Yeast pathway kit: a method for metabolic pathway assembly with automatically simulated executable documentation. ACS Synth. Biol. 5, 386-394. https://doi.org/10.1021/acssynbio.5b00250. 
Pereira, F.B., Guimaraes, P.M.R., Teixeira, J.A., Domingues, L., 2010. Selection of Saccharomyces cerevisiae strains for efficient very high gravity bio-ethanol fermentation processes. Biotechnol. Lett. 32, 1655-1661. https://doi.org/10.1007/s10529010-0330-9.

Pereira, F.B., Romani, A., Ruiz, H.A., Teixeira, J.A., Domingues, L., 2014. Industrial robust yeast isolates with great potential for fermentation of lignocellulosic biomass. Bioresour. Technol. 161, 192-199. https://doi.org/10.1016/j.biortech.2014.03.043.

Perez-Bibbins, B., de Souza Oliveira, R.P., Torrado, A., Aguilar-Uscanga, M.G., Dominguez, J.M., 2014. Study of the potential of the air lift bioreactor for xylitol production in fed-batch cultures by Debaryomyces hansenii immobilized in alginate beads. Appl. Microbiol. Biotechnol. 98, 151-161. https://doi.org/10.1007/s00253013-5280-4.

Petersen, G., Werpy, T., 2004. Top value added chemicals from biomass. Program.

Ping, Y., Ling, H.Z., Song, G., Ge, J.P., 2013. Xylitol production from non-detoxified corncob hemicellulose acid hydrolysate by Candida tropicalis. Biochem. Eng. J. 75, 86-91. https://doi.org/10.1016/j.bej.2013.03.022.

Rivas, B., Domínguez, J.M., Domínguez, H., Parajó, J.C., 2002. . Bioconversion of posthydrolysed autohydrolysis liquors: an alternative for xylitol production from corn cobs. Enzyme Microb. Technol. 31, 431-438.

Rivas, B., Torre, P., Dominguez, J.M., Converti, A., Parajo, J.C., 2006. Purification of xylitol obtained by fermentation of corncob hydrolysates. J. Agric. Food Chem. 54, 4430-4435. https://doi.org/10.1021/jf053156x.

Rodríguez-López, J., Romaní, A., González-Muñoz, M.J., Garrote, G., Parajó, J.C., 2012. Extracting value-added products before pulping: Hemicellulosic ethanol from Eucalyptus globulus wood. https://doi.org/10.1515/hf-2011-0204.

Romaní, A., Garrote, G., Alonso, J.L., Parajó, J.C., 2010a. Bioethanol production from hydrothermally pretreated Eucalyptus globulus wood. Bioresour. Technol. 101, $8706-8712$.

Romaní, A., Garrote, G., Alonso, J.L., Parajó, J.C., 2010b. Experimental assessment on the enzymatic hydrolysis of hydrothermally pretreated eucalyptus globulus wood. Ind. Eng. Chem. Res. 49, 4653-4663. https://doi.org/10.1021/ie100154m.

Romani, A., Pereira, F., Johansson, B., Domingues, L., 2015. Metabolic engineering of
Saccharomyces cerevisiae ethanol strains PE-2 and CAT-1 for efficient lignocellulosic fermentation. Bioresour. Technol. 179, 150-158. https://doi.org/10.1016/j.biortech. 2014.12.020.

Ruiz, H.A., Rodríguez-Jasso, R.M., Fernandes, B.D., Vicente, A.A., Teixeira, J.A., 2013 Hydrothermal processing, as an alternative for upgrading agriculture residues and marine biomass according to the biorefinery concept: a review. Renew. Sustain Energy Rev. 21, 35-51.

Subtil, T., Boles, E., 2012. Competition between pentoses and glucose during uptake and catabolism in recombinant Saccharomyces cerevisiae. Biotechnol. Biofuels 5, 14. https://doi.org/10.1186/1754-6834-5-14.

Traff, K.L., Otero Cordero, R.R., van Zyl, W.H., Hahn-Hagerdal, B., 2001. Deletion of the GRE3 aldose reductase gene and its influence on xylose metabolism in recombinant strains of Saccharomyces cerevisiae expressing the xylA and XKS1 genes. Appl. Environ. Microbiol. 67, 5668-5674. https://doi.org/10.1128/AEM.67.12.56685674.2001.

Van Dijken, J.P., Bauer, J., Brambilla, L., Duboc, P., Francois, J.M., Gancedo, C., Giuseppin, M.L.F., Heijnen, J.J., Hoare, M., Lange, H.C., Madden, E.A., Niederberger, P., Nielsen, J., Parrou, J.L., Petit, T., Porro, D., Reuss, M., van Riel, N., Rizzi, M., Steensma, H.Y., Verrips, C.T., Vindeløv, J., Pronk, J.T., 2000. An interlaboratory comparison of physiological and genetic properties of four Saccharomyces cerevisiae strains. Enzyme Microb. Technol. 26, 706-714.

Venkateswar Rao, L., Goli, J.K., Gentela, J., Koti, S., 2016. Bioconversion of lignocellulosic biomass to xylitol: an overview. Bioresour. Technol. 213, 299-310. https://doi.org/10.1016/j.biortech.2016.04.092.

Watanabe, S., Abu Saleh, A., Pack, S.P., Annaluru, N., Kodaki, T., Makino, K., 2007. Ethanol production from xylose by recombinant Saccharomyces cerevisiae expressing protein-engineered NADH-preferring xylose reductase from Pichia stipitis. Microbiology 153, 3044-3054. https://doi.org/10.1099/mic.0.2007/007856-0.

Zabed, H., Sahu, J.N., Boyce, A.N., Faruq, G., 2016. Fuel ethanol production from lignocellulosic biomass: an overview on feedstocks and technological approaches. Renew. Sustain. Energy Rev. 66, 751-774. 